This article was downloaded by: [Passarelli, Lilian Mónica]

On: 21 March 2010

Access details: Access Details: [subscription number 919935564]

Publisher Taylor \& Francis

Informa Ltd Registered in England and Wales Registered Number: 1072954 Registered office: Mortimer House, 3741 Mortimer Street, London W1T 3JH, UK

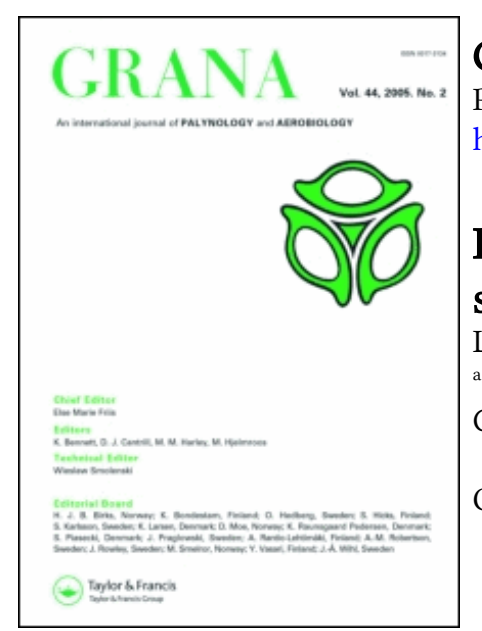

\title{
Grana
}

Publication details, including instructions for authors and subscription information:

http://www.informaworld.com/smpp/title $\sim$ content=t713648917

\section{Pollen grains and massulae in pollinia of four South American palustrine species of Habenaria (Orchidaceae)}

Lilian M. Passarelli a; Cristina H. Rolleri ${ }^{a}$

${ }^{a}$ Laboratorio de Estudios de Anatomía Vegetal Evolutiva y Sistemática (LEAVES), Facultad de Ciencias Naturales y Museo de La Plata, La Plata, Argentina

Online publication date: 17 March 2010

To cite this Article Passarelli, Lilian M. and Rolleri, Cristina H.(2010) 'Pollen grains and massulae in pollinia of four South American palustrine species of Habenaria (Orchidaceae)', Grana, 49: 1, $47-55$

To link to this Article: DOI: $10.1080 / 00173130903484869$

URL: http://dx.doi.org/10.1080/00173130903484869

\section{PLEASE SCROLL DOWN FOR ARTICLE}

\footnotetext{
Full terms and conditions of use: http://www.informaworld.com/terms-and-conditions-of-access.pdf

This article may be used for research, teaching and private study purposes. Any substantial or systematic reproduction, re-distribution, re-selling, loan or sub-licensing, systematic supply or distribution in any form to anyone is expressly forbidden.

The publisher does not give any warranty express or implied or make any representation that the contents will be complete or accurate or up to date. The accuracy of any instructions, formulae and drug doses should be independently verified with primary sources. The publisher shall not be liable for any loss, actions, claims, proceedings, demand or costs or damages whatsoever or howsoever caused arising directly or indirectly in connection with or arising out of the use of this material.
} 


\title{
Pollen grains and massulae in pollinia of four South American palustrine species of Habenaria (Orchidaceae)
}

\author{
LILIAN M. PASSARELLI \& CRISTINA H. ROLLERI \\ Laboratorio de Estudios de Anatomía Vegetal Evolutiva y Sistemática (LEAVES), Facultad de Ciencias Naturales y Museo \\ de La Plata, La Plata, Argentina
}

\begin{abstract}
The massulae and pollen grains in pollinia of four palustrine South American species of Habenaria, H. bractescens, H. gourlieana, $H$. paucifolia and $H$. secunda were studied here for the first time using light, scanning, and transmission electronic microscopy. The pollinia have acalymmate, piriform or tabular massulae. Filiform elastoviscin threads are formed between the pollen grains of pollinia, allowing them to stick together. The pollen grains are inaperturate, grouped into calymmate tetrads, and have reticulate or reticulum-like, heterobrochate exine. Reticulate ornamentation consists of irregular, rounded, wide or narrow, continuous muri, while reticulum-like ornamentation is formed by discontinuous, partial muri, superficially smooth or with spherical micro-granules, intermingling with some isolated elements that can be interpreted as pila. The wall structure of individual pollen grains differs according to their position in the tetrads: outside walls develop complete exine and intine, with columellae, while the walls inside the pollinium lack exine or develop only a much reduced one. Palynological characters differentiate the species: pyriform massulae, triangular in outline, occur in $H$. gourlieana, $H$. paucifolia and $H$. secunda, while tabular massulae, oblong in outline, characterise $H$. bractescens. Ornamentation also distinguishes $H$. gourlieana grains, with interrupted, discontinuous muri, from the other three species, bearing reticulate grains. Elastoviscin filiform threads, which were found to be lipidic in nature, are simple or ramified, and some bear pores (in $H$. bractescens). Branched filiform threads characterise $H$. bractescens and $H$. secunda, while unbranched, filiform threads correspond to $H$. gourlieana and $H$. paucifolia.
\end{abstract}

Key words: Acalymmate massulae, calymmate tetrads, inaperturate pollen grains, filiform threads

The morphology of pollen grains and massulae in pollinia of Habenaria bractescens Lindl., H. gourlieana Gillies ex Lindl., $H$. paucifolia Lindl. and $H$. secunda Lindl., together with the analysis of the composition of the filiform threads of the pollinia, were investigated with the intention of determining the value of these features in the systematic of the genus, and make a contribution at the taxonomy and phylogeny of the group.

The genus Habenaria Willd. is represented by some 600 terrestrial and palustrine, most rarely epiphytic species, distributed in pantropical temperate zones. It is characterised by plants with thick fleshy roots, tuberose, simple or lobulate rhizomes, lanceolate or ovate leaves with sheathing base, terminal inflorescences bearing large or small, resupinate, white, green or, most uncommonly, pink to dark pink, yellow or orange flowers with the dorsal sepal short or long, sometimes carnose at the apex, straight or reflex anther, two claviform or pyriform pollinia, a short or long caudicle, and a small naked viscidium.

The characterisation of the genus Habenaria is complex, because most of the diagnostic characters applied to their systematics are the florals, which may become difficult or inaccessible when studies are based on herbarium material. According to GarciaCruz et al. (2000) there are numerous names published (about 1762 according to the Index Kewensis), but they estimated that there are still little known, or

Correspondence: Lilian M. Passarelli, LEAVES (Laboratorio de Estudios de Anatomía Vegetal Evolutiva y Sistemática), Facultad de Ciencias Naturales y Museo de La Plata, Universidad Nacional de La Plata, 64 entre 120 y diagonal 113, B1904 DZB, La Plata, República Argentina. E-mail: lmpassarelli@yahoo.com.ar 
not even described species of the genus. The authors listed 41 taxa only from Mexico. There are 14 species growing in Argentina, 13 of which are also found in Brazil and one in Chile (Correa, 1951).

Ames (1910) published the first known revision of Habenaria, but his work only deals with 75 species from Northern America, also including Pyperia Rydb., and Platanthera Rich. subg. Habenaria, both currently treated as distinct genera by other authors, such as Kurzweil and Weber (1992), who also added to Habenaria the genera: Bonatea Willd., Centrostigma Schltr., and Platycoryne Rchb.f., and Pridgeon et al. (2001). Batista et al. (2006) reviewed Habenaria sect. Macroceratitae, a section characterised by the presence of long, separated, involuted stigmatic processes, recognising seven species, including $H$. bractescens and $H$. gourlieana, from central, south, and south-east of Brazil, and southern South America.

Habenaria bractescens and $H$. secunda are pantropical, perennial herbs, while $H$. gourlieana and $H$. paucifolia have a more restricted geographical distribution, and are annual geophytes.

In Argentina, Habenaria bractescens grows in the north-western provinces Jujuy, Salta, and Tucumán, in the north-eastern provinces, Formosa, Misiones, Chaco, Corrientes and Entre Rios, and the Córdoba Province, in the centre of the country; plants are creeping or have a rosette habit, distinguished by a dense pubescence throughout, and grow in very moist, sunny areas. Habenaria secunda has been found only in the mesopotamian provinces (Misiones, Corrientes, and Entre Rios); the species is characterised by its pendulous inflorescences that bear yellow or green flowers. Habenaria gourlieana is popularly known in Argentina as "butterfly orchid"; the species produces delicate white flowers that emit jasmine-like perfume at night, is very common in Misiones and Corrientes provinces, living in marshes, wetlands and flooded lands.

Habenaria paucifolia grows in Argentina and Chile. In Argentina, it inhabits moist grasslands, wet dunes, and small pedemontane wetlands, with sandy soils, of the provinces of La Rioja, Mendoza, San Juan, Buenos Aires, Neuquén, and Rio Negro. In Chile it occurs from the south of the province of Atacama to the canal Smith, $48^{\circ} \mathrm{S}$, in wet grasslands. Although Traub and Moldenke (1949) cited the species for the wetlands of Quillota, recent floristic studies (CONAF, Corporación Nacional Forestal Región de Valparaíso, 2007) suggest that it could be regionally extinct. The species grows to form dense colonies due to its profuse vegetative reproduction which led to continuous production of new tubers at the end of long rhizomes, and plants bear small green flowers.
Studies on the palynology of Orchidaceae such as those of Ackerman and Williams (1980, 1981), and Fitzgerald et al. (1994) indicate that the pollen and pollinia provide useful diagnostic features in suprageneric categories. In the case of Habenaria and its status as a genus, palynological works are relatively scarce; these include both general and related to the ultrastructure of the wall, such as those of Cocucci and Jensen (1969), Schill and Pfeiffer (1977), Burns-Balogh (1983), Hesse and Burns-Balogh (1984), Zavada (1990), and Schlag and Hesse (1993). Singer (2001) studied the biology of pollination in $H$. parviflora Lindl. from Brazil.

The filiform threads that are formed between the grains of pollen in the pollinia, allowing its adhesion, were called viscin threads by Jackson (1928). Different compositions were attributed to these threads such as sporopollenin, if they originate in the ectexine, before the synthesis of pollenkitt, and are acetolysis-resistant (Hesse, 1981a, b; Punt et al., 2007), or others, such as mucilaginous compounds, pectin, cellulose, materials produced by the disintegration of the tapetum, and thus not acetolysis-resistant. Hesse and Burns-Balogh (1984) analysed these filiform elements in several species of Habenaria, not included in this study, and determined they were lipidic in nature, and also calling them elastoviscin threads (Hesse, 1986; Hesse \& BurnsBalogh, 1984). In this work, together with the morphology of pollen grains and massulae in the pollinia of the four species of Habenaria, new tests are performed to determine the chemical nature of the filiform threads of the pollinia.

\section{Materials and methods}

All pollinia samples were obtained from voucher specimens from the Facultad de Ciencias Naturales UNLP y Museo de La Plata (LP) and the Instituto de Botánica Darwinion, CONICET (SI) herbaria. Fresh material of Habenaria gourlieana was also used.

The pollinia and the massulae were analysed by stereoscopic, light (LM), scanning (SEM), and transmission (TEM) electronic microscopy. Pollinia were mounted without treatment on metal stubs with adhesive double face tape, covered with goldpalladium under vacuum, and examined by a JEOL T 100 microscope from the Electronic Microscopy Service from the Facultad de Ciencias Naturales UNLP y Museo de La Plata.

For TEM observations of the pollinia of $H$. gourlieana, fresh material was fixed in $2.5 \%$ glutaraldehyde in sodium cacodylate buffer $1.5 \mathrm{M}(\mathrm{pH} 7)$ during three hours. After washing in buffer, the pollen was post-fixed for one hour with $\mathrm{OsO}_{4}$ in 
aqueous solution. The dehydration was carried out in acetone, and then embedded in Spurr's embedding. The procedures were carried out at room temperature. Sections were post stained in uranylacetate (15 minutes) and lead-citrate (2 minutes), and observed with a ZEISS T 109 electron microscope at the LANAYS-CONICET Institute.

For observations with light microscope (LM), thin sections from material treated for MET were used.

The acetolysis method of Erdtman (1960) collapses the pollens grains, but it allows observing the composition and resistance of the filiform threads present on their surface. The lipidic nature of these threads was detected in fresh material with $0.01 \%$ Nile blue sulphate aqueous (Cain, 1947), a dye which give a colour reaction with both acid and neutral lipids. The reaction was observed using an epifluorescence microscope.

The flower size (small, medium, large) applies only to flowers of the species studied. Pollen terminology follows Punt et al. (2007).

\section{Results}

The pollinia are the dispersal units of coherent massulae of pollen grains. The flowers of the four studied species of Habenaria have two pollinia, one per microsporangium (anther). The pollinia consist of two hemipollinia, the caudicle, and the retinaculum or viscidium. The pollinia have acalymmate massulae, each one formed by calymmate tetrads of pollen grains (Figure 1B, D-F).

The massulae are more or less pyriform in shape, triangular in outline, or more or less tabular in shape, oblong in outline, both types with blunt edges. Their sizes vary with the species, but always arranged radially, thus obtaining the best use of available space. Pyriform massulae were found in Habenaria gourlieana (Figure 1A), H. paucifolia (Figure 1B) and H. secunda (Figure 1C, D), while tabular massulae were observed in $H$. bractescens (Figure 1E, F).

The tetrads are uniplanar, with quadrangular (Figure 4A) or rhombic outline, or multiplanar, tetrahedral (Figure 4C) and decussate. Although uniplanars are the most frequent, the two types are usually present in the same massula.

The pollen grains are inaperturate (Figure 2D); they have reticulate or reticulum-like, heterobrochate exine. Reticulate ornamentation consists of irregular, rounded, wide or narrow, continuous muri (Figures 2, 3). Reticulum like ornamentation is formed by discontinuous partial muri, superficially smooth or with spherical micro-granules; muri intermingle with some isolated elements that can be interpreted as pila (Figure 3D).
Abnormal pollen grains embedded within elastoviscin are often found in the caudicle, next to the pollinia. The ornamentation of these grains is microechinate.

Filiform elements, easily visible with LM, are found on surface of pollen grains, among the massulae (Figures 1E, 2A-D). These threads have a cordlike, sometimes hollow structure (Figure 2A); can be simple or ramified, and occasional pores may occur. These threads sometimes seems to be only a sticky, pollenkitt-like substance adhered to the surface of grains (Figure 2D).

Branched filiform threads are characteristics of Habenaria bractescens (Figure $2 \mathrm{~B}$ ) and $H$. secunda (Figure 2C), while simple ones were found in $H$. gourlieana (Figure 2D) and $H$. paucifolia (Figure 2A). Pores are present in threads of $H$. bractescens (Figures 2B, 3A) and absent in $H$. gourlieana, $H$. paucifolia and $H$. secunda. These threads hold the massulae together, giving adhesion and flexibility at the same time.

Tests performed indicate that filiform elements of these species do not resist acetolysis treatment, and dissolve with organic solvents. Tests performed using basic fuchsine, together with the results of the acetolysis method, clearly indicate absence of sporopollenin. The colour reaction to the Blue Nile tests shows mainly a lipid composition, since fatty acids gives a blue-greenish colour reaction, which can be observed with the epifluorescence microscope.

In TEM, the walls of the grains of tetrads have a different structure according to the location in pollinia, a condition only illustrated in Habenaria gourlieana (Figure 4B, D-F). External walls have a complete, columellate ectexine, with pollenkitt between columellae, and over partial muri (Figure $4 \mathrm{D}, \mathrm{E})$. The contact walls between grains are extremely reduced with dense globular inclusions partially embedded within the intine (Figure 4B, F).

Viability tests performed in Habenaria gourlieana indicate high fertility values $( \pm 99 \%$ average of germination).

\section{Descriptions of the species}

Habenaria bractescens (Figures 1E, F, 2A, 3B; Table I). - Medium sized flowers. Massulae tabular, rectangular to oblong in outline, $0.20 \mathrm{~mm}$ long. Inaperturate pollen grains. Exine reticulate, semitectate, reticulum heterobrochate. Irregular, thin, 2.9 $\mu \mathrm{m}$ wide muri, delimiting small lumina. Branched filiform threads, with pores.

Habenaria gourlieana (Figures $1 A, 2 D, 3 D, 4 A-F$; Table I). - Large sized flowers. Pyriform or pyramidal, massulae triangular in outline, $0.35 \mathrm{~mm}$ long. 

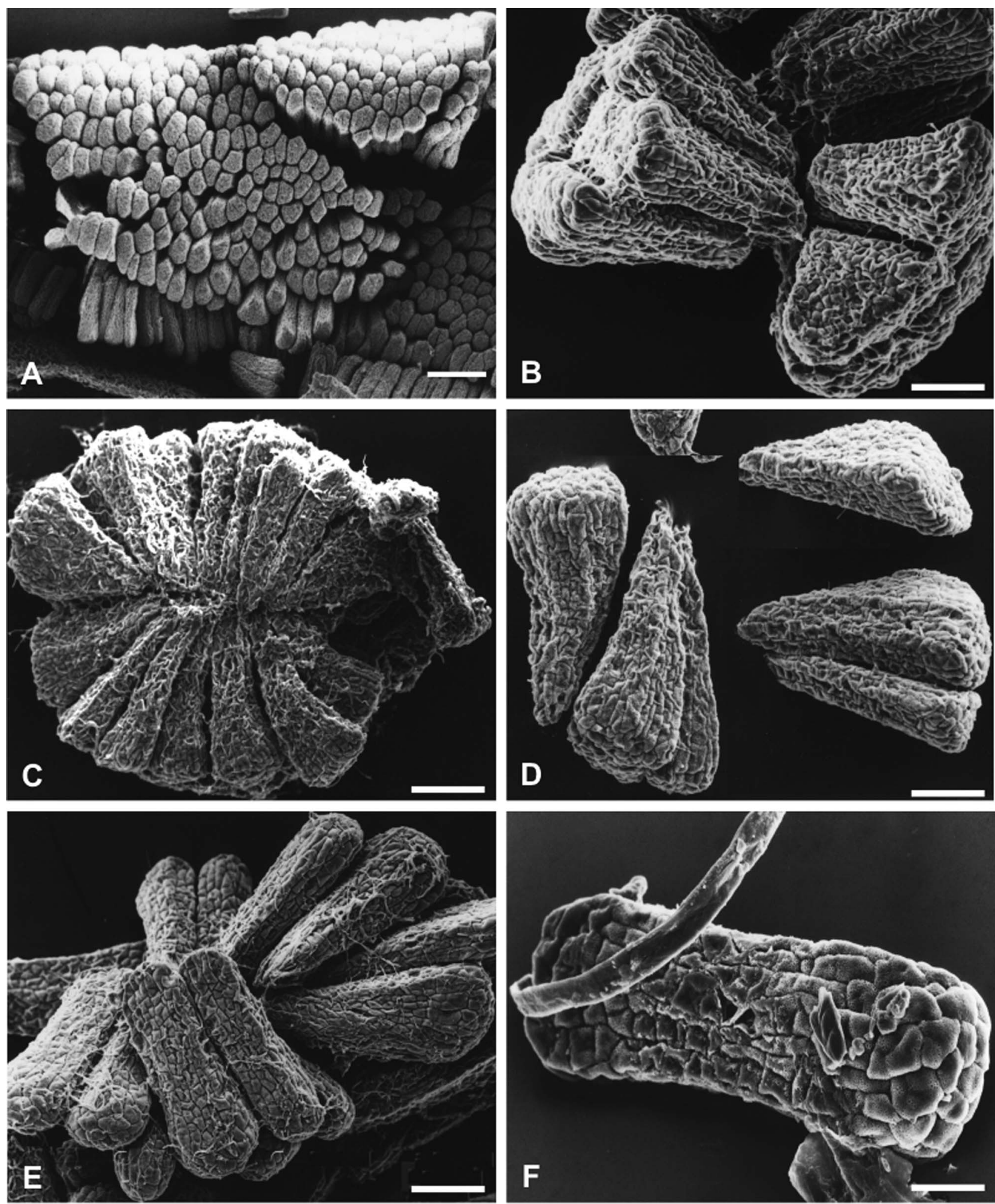

Figure 1. Pollinium and massulae in Habenaria species. A. Pollinium of $H$. gourlieana; B. Loose massulae from a pollinium of $H$. paucifolia; C, D. Massulae of $H$. secunda: C. Radially arranged, triangular in outline massulae; D. Loose massulae. E, F. Massulae of $H$. bractescens: $\mathbf{E}$. Part o a pollinium with a group of tabular massulae and elastoviscin threads; F. An isolated, tabular, oblong in outline massula. Scale bars $-0.35 \mathrm{~mm}(\mathrm{~A}) ; 110 \mu \mathrm{m}(\mathrm{B}, \mathrm{C}) ; 70 \mu \mathrm{m}(\mathrm{D}, \mathrm{E}) ; 30 \mu \mathrm{m}(\mathrm{F})$. 

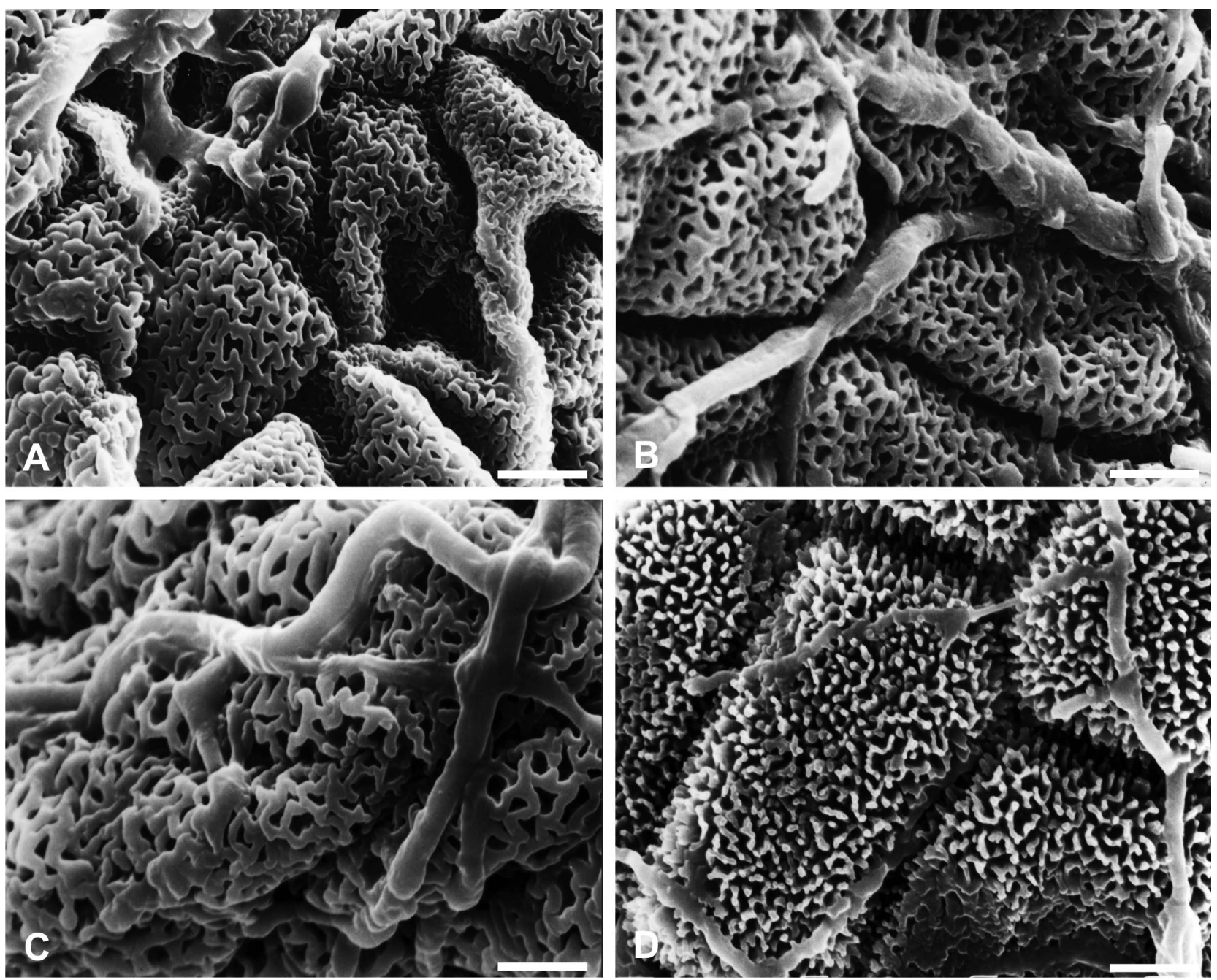

Figure 2. Details of massulae and elastoviscine threads in Habenaria species. A-C. Ramified elastoviscin, apparently hollow threads in: A. $H$. paucifolia; B. $H$. bractescens (elastoviscin threads showing pores); C. $H$. secunda. D. Massula of $H$. gourlieana, viscous elastoviscin threads and pollenkit-like substance on massulae. Scale bars $-5 \mu \mathrm{m}(\mathrm{A}-\mathrm{D})$.

Inaperturate pollen grains. Exine with broken, incomplete reticulum, intectate, formed by partial muri, superficially smooth or covered with spherical micro-granules, heterobrochate, $2.9 \mu \mathrm{m}$ wide, delimiting small lumina. Simple filiform threads without pores, in some areas with the appearance of pollenkitt-like substance.

Habenaria paucifolia (Figures 1B, 2A, 3B; Table I). Small sized flowers. Pyriform in shape and triangular massulae, $0.15 \mathrm{~mm}$ long. Inaperturate pollen grains. Exine reticulate, semitectate, reticulum heterobrochate. Irregular, thin, $1.5 \mu \mathrm{m}$ wide muri delimiting small lumina. Branched, hollow filiform threads, without pores.

Habenaria secunda (Figures 1C, D, 2C, 3C; Table I). - Small sized flowers. Pyriform or pyramidal, massulae triangular in outline and $0.25 \mathrm{~mm}$ long. Inaperturate pollen grains. Exine reticulate, semitectate, reticulum heterobrochate. Irregular muri, with complete walls, twice the thickness of the previous species, $6.4 \mu \mathrm{m}$ wide, delimiting large lumina. Simple filiform threads, coarse and thick.

\section{Discussion}

During a palynological study of four species of Habenaria, $H$. bractescens, $H$. gourlieana, $H$. paucifolia and $H$. secunda, several characters were found to characterise the species, such as the shape and outline of the massulae, and the exine ornamentation of pollen grains. Conclusions were also made on the wall structure and the chemical nature of filiform threads found inside pollinia.

Pyriform in shape, triangular in outline massulae were found in Habenaria gourlieana, $H$. paucifolia and $H$. secunda, while tabular, oblong in outline 

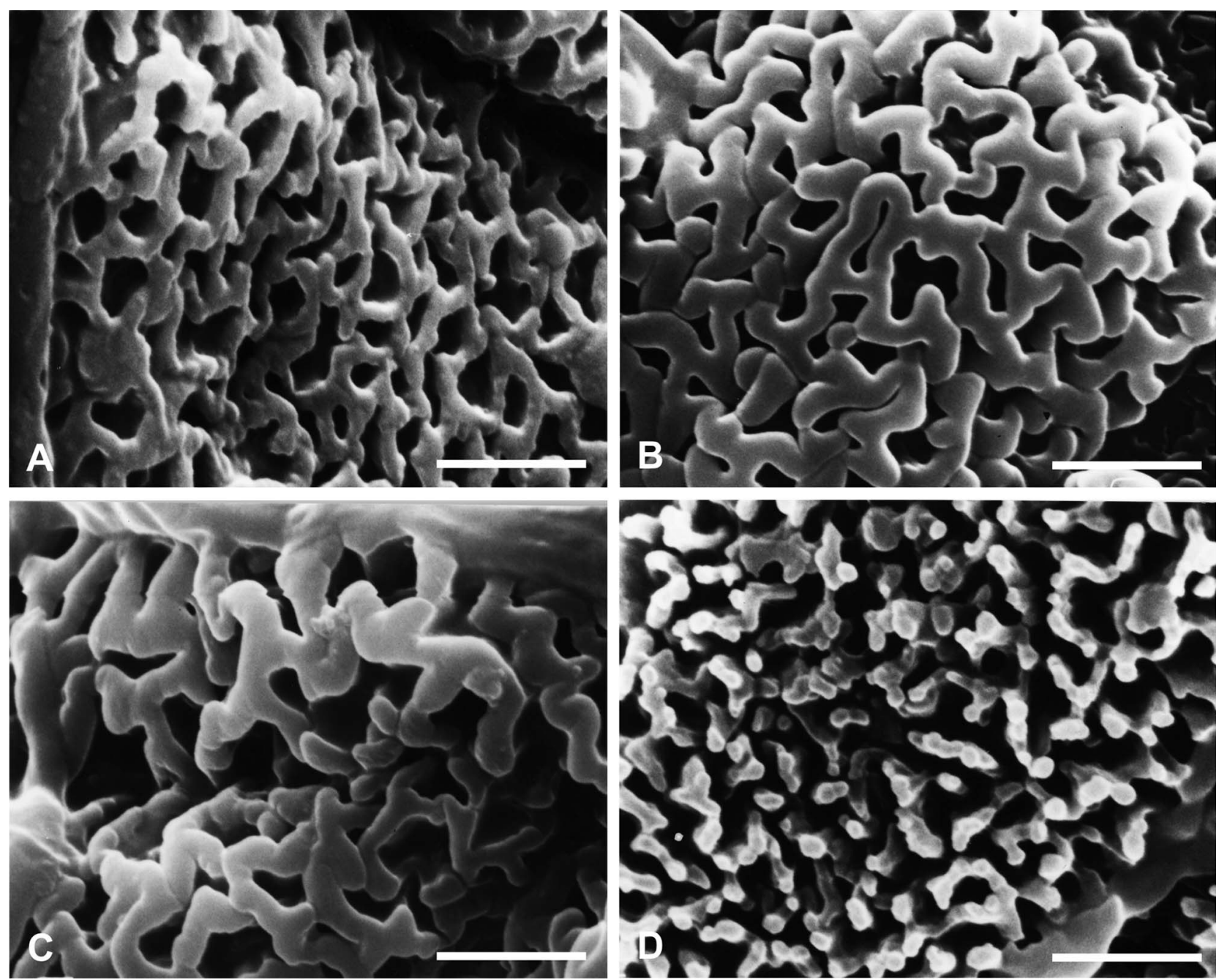

Figure 3. Types of walls in Habenaria species. A. Reticulum with rounded, thin, continuous muri of H. bractescens, and elastoviscin thread with pores. B, C. Coarse, thick muri in: B. H. paucifolia; C. H. secunda. D. Interrupted, broken, discontinuous muri, with granules over them, and isolated elements, possible pila in $H$. gourlieana. Scale bars $-3 \mu \mathrm{m}$.

massulae characterises $H$. bractescens. The uniplanar and multiplanar tetrads present in the same massula are common in Orchidaceae, and the four studied species are not an exception.

Ornamentation of exine allowed to distinguish between species. Reticulate, heterobrochate grains were found in Habenaria bractescens, $H$. paucifolia and $H$. secunda, where the reticulum is continuous, with narrow or wide, rounded muri.

Habenaria gourlieana differs from the others by its reticulum-like ornamentation, formed by discontinuous, partially intectate muri, superficially smooth or with spherical micro-granules; the muri intermingle with some isolated elements that can be interpreted as pila. Partially intectate muri are uncommon in the genus, they were only previously observed in $H$. medusa Kränzlin, in illustrations of pollen grains made by Schill and Pfeiffer (1977); however, these authors did not analyse the differences between species of Habenaria in connection with the ornamentation of pollen grains. Chesselet and Linder (1993) described this type of ornamentation for Bonatea pulchella Summerh., as a reticulum with reduced to absent muri, thus intectate.

Wall structure of individual pollen grains differ according to their position in the tetrads: outside walls develop both complete exine and intine, with columellae, while the walls inside pollinium lack exine or develop only a very much reduced one, a condition showed by other genera and species of Orchidoideae (Pacini \& Hesse, 2002).

According to the observations made here, palynological characters of Habenaria bractescens, $H$. paucifolia and $H$. secunda are similar to those of other species 

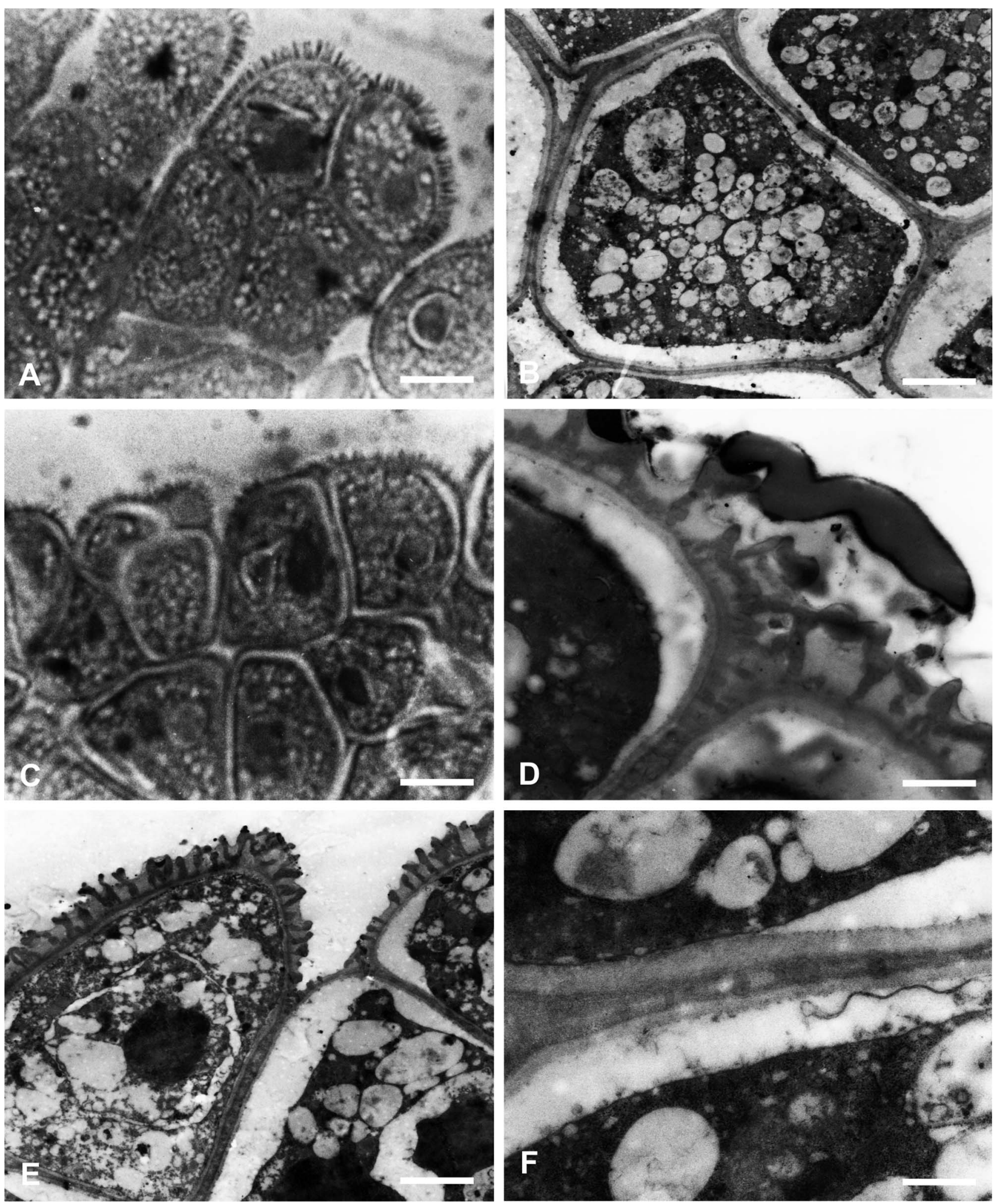

Figure 4. Wall structure in Habenaria gourlieana. A, C. LM \& B, D-F. TEM. A. Quadrangular external tetrad. B. Inner grains with exine without reticulum, and wide intine. C. Tetragonal and other types of tetrads. D. Pollen wall (detail), partial muri and pila with pollenkit inside and over. E. External grains of tetrads with reticulum-like exine, pollenkit present among baculae. F. Detail of wall in internal pollen grains with intine and granular exine. Scale bars - $10 \mu \mathrm{m}(\mathrm{A}, \mathrm{C}) ; 5 \mu \mathrm{m}(\mathrm{B}, \mathrm{E}) ; 0.5 \mu \mathrm{m}(\mathrm{D}, \mathrm{F})$. 
Table I. Comparison of floral and palynological characters of species of Habenaria.

\begin{tabular}{lllll}
\hline Characters & H. bractescens & H. gourlieana & H. paucifolia & H. secunda \\
\hline Size of spur, mm & 60 (medium) & 100 (large) & 14 (small) & 7 (small) \\
Size of labellum, mm & 10 & 16 & 7.5 & 8 \\
Size of sepals, mm & 17 & 40 & 7 & 7 \\
Massulae shape & Tabular & Piriform & Triangular & Piriform \\
Massulae outline & Oblong & $0.35 \pm 0.002$ & $0.15 \pm 0.007$ & Triangular \\
Massulae size, mm & $0.20 \pm 0.004$ & Discontinuously reticulate & Reticulate & $0.25 \pm 0.005$ \\
Ornamentation of pollen grains & Reticulate & $2.9 \pm 0.5$ & $5 \pm 0.9$ & Reticulate \\
Muri or pila width, $\mu \mathrm{m}$ & $2.9 \pm 0.2$ & Branched, without pores & $6.4 \pm 1.2$ \\
Threads & Branched, with pores & Simple, without pores & &
\end{tabular}

of this genus (Hesse \& Burns-Balogh, 1984), while $H$. gourlieana differs clearly from the other three. Instead, $H$. gourlieana has discontinuous reticulum, being closer to some species of Bonatea (Chesselet \& Linder, 1993). As stated earlier, $H$. bractescens, $H$. paucifolia and $H$. secunda have reticulate exine with a heterobrochate, continuous reticulum. BurnsBalogh (1983) considered that the semitectate condition of exine in Orchidaceae is just a stage in the evolution to an intectate type of exine. If so, $H$. gourlieana has the most evolved wall structure among the species studied here.

The sporoderm has a different structure in the grains according to their position in the pollinium, with the external grains characterised by a semitectate wall and the internal grains with reduced wall, i.e. formed only by endexine and intine. This modified sporoderm could be explained by the fact that the internal grains are not exposed to dehydration. The trait has been observed in grains of other genera of Orchidaceae, also with dispersal units consisting of pollinia, such as Polystachia pubescens Reich. (Schlag \& Hesse, 1993) and Epidendrum scutella Lindl. (Cocucci \& Jensen, 1969).

Micro-echinate abnormal pollen grains, embedded within elastoviscin were found in the caudicle, next to the pollinia. The character was mentioned by Hesse and Burns-Balogh (1984) for Habenaria genuflexa Rendle from Africa, and by Takahashi (1980) for Hemerocallis L. (Liliaceae), the later referring to microspores with a verrucate wall that gradually evolves to a reticulate type during the development of the walls. It is possible to consider these micro-echinate pollen grains in Habenaria as one maturation stage in the consolidation of the typical reticulum.

Filiform threads, simple or ramified, were found on the surface of pollen grains among the massulae. These cord-like structures that join the pollen grains together seem to be hollow and have occasional pores, but since elastoviscin is viscous, gum-like, pressure may induce their adherence to the surface of grains in some areas. Tests performed indicate that filiform threads do not resist acetolysis treatment and dissolve with organic solvents; sporopollenin is absent and their composition is mainly lipidic in nature. The presence of elastoviscin in all subfamilies of the Orchidaceae is mentioned by Schill and Wolter (1986), and Pacini and Hesse (2002), the last authors considering this substance similar to the pollenkitt. In the species studied here, a combination of threads and also an amorphous substance, pollenkitt-like, lipidic in nature, was detected.

The high reproductive success, known for the Orchidaceae in general, may be accomplished in Habenaria species both through their specialisation in pollen dispersion and the viability of pollen grains, close to a $100 \%$.

\section{Conclusions}

The palynological study performed allows conclusions to be drawn on morphology, systematics, and contributes to the phylogeny. The pollinia, the ornamentation of pollen grains, the variations in structure of sporoderm in grains of the same tetrad, the types of reticulum, the chemical nature of elastoviscin filiform elements found in the massulae, and the viability of pollen grains were studied for the first time for these palustrine species of orchids. The palynological characters distinguish the species, and are diagnostic at the specific level. Of the four species, Habenaria gourlieana supplies also suggestive information regarding the evolution of certain traits. The finding of micro-echinate grains in the caudicle suggests a way the walls of grains evolve to the mature, typical reticulate type, common in Habenaria. The continuous reticulum, which is the most common type in the group, could also evolve from the semitectate condition of exine in Orchidaceae to an intectate type of exine, such as that seen in $H$. gourlieana. If the continuous reticulum is interpreted as being just a stage in this evolution, $H$. gourlieana represents the most evolved wall structure among the species under study, a conclusion that can be considered a working hypothesis for the genus. 


\section{Acknowledgements}

This work was conducted at the Laboratorio de Estudios de Anatomía Vegetal Evolutiva y Sistemática (LEAVES), Facultad de Ciencias Naturales y Museo de La Plata; supported by the Programa de Incentivos para Docentes Investigadores de la Universidad de La Plata, and the Consejo de Investigaciones Científicas y Técnicas (CONICET, Buenos Aires). The authors gratefully acknowledge Dr Silvana Martén-Rodríguez, Smithsonian Institution (Washington, D.C.) for the revision of the English language version. The authors also thank Raquel Piñeyro, who carefully prepared the illustrations.

\section{Specimens investigated}

Habenaria bractescens Lindl. ARGENTINA, Buenos Aires: Isla Martín García, 5/12/1992, Hurrell 1193 (LP); Isla Martín García, 15/11/1995, Hurrell 2413 (LP); Isla Martín García, 15/ 12/1991, Correa 909 (LP); Isla Santiago, 21/2 /1931, Cabrera 1666 (LP).

H. gourlieana Gillies ex Lindl. ARGENTINA, Buenos Aires: General. Madariaga, Dunas de Juancho, 9/12/67, Boelcke 6294 (BAA); Partido de La Costa, Villa Gessell, 23/1/73, Boelcke 14452 \& 54 (BAA); Villa Gessell, 30/1/72, Boelcke 14553 (BAA); Villa Gessell, 2/62, Boelcke \& Nicora 2802 (BAA); La Lucila del Mar, 14/2/72, Boelcke 14645 (BAA); Mar del Tuyú, 15/1/91, Rivero \& Roitman 21904 (BAA); San Bernardo, 29/1/84, Cámara Hernández 19031 (BAA); Monte Hermoso, 10/2/73, Arroyo 14170 (BAA). Corrientes: Departamento Empedrado, Estancia La Yela, 21/12/1972, Pedersen 10271 (LP). La Rioja: Departamento General Lavalle, 1/2/42, Meyer 4141(LP). San Juan: Calingasta, 9/12/60, Fabris \& Marchioni 2390 (LP).

H. paucifolia Lindl. ARGENTINA: Neuquén, 3/1942, de Saint 12770 (SI). CHILE: Coquimbo, 17/1/36, Cabrera 3505 y 21821 (LP).

H. secunda Lindl. ARGENTINA, Corrientes: Departamento Lavalle, 24/11/71, Pedersen 10009 (SI). BRASIL, Paraná: Pereira 8323 (HB); Paraná, Pabst 7598 (HB 30656); Paraná, s. coll. (LP). São Paulo, 16/1/52, s. coll. (HB 1309). Rio de Janeiro: Teresópolis, 24/2/63, Pabst s. n. (LP); Petrópolis, 3/3/ 63, s. coll., s. n. (HB 25272 \& HB 25301).

\section{References}

Ames, O. (1910). The genus Habenaria in North America. Orchidaceae, 4, 1-288.

Ackerman, J. D. \& Williams, N. (1980). Pollen morphology of the Tribe Neottieae and its impact on the classification of the Orchidaceae. Grana, 19, 7-18.

Ackerman, J. D. \& Williams, N. H. (1981). Pollen morphology of the Chloraeinae (Orchidaceae: Diurideae) and related subtribes. Am. F. Bot., 68, 1392-1402.

Batista, J. A. N., de Bem Bianchetti, L. \& Miranda, Z. J. G. (2006). A revision of Habenaria section Macroceratitae (Orchidaceae) in Brazil. Brittonia, 58, 10-41.

Burns-Balogh, P. (1983). A theory on the evolution of the exine in Orchidaceae. Am. F. Bot., 70, 1304-1312.
Cain, A. J. (1947). The use of Nile blue in the examination of lipids. Q. F. Microsc. Sci., 88, 383-392.

Chesselet, P. \& Linder, H. P. (1993). Pollen morphology of the Diseae (Orchidoideae; Orchidaceae). Grana, 32, 101-110.

Cocucci, A. E. \& Jensen, W. A. (1969). Orchid embryology: Pollen tetrads of Epidendrum scutella in the anther and on the stigma. Planta, 84, 215-229.

CONAF (Corporación Nacional Forestal/Región de Valparaíso) (2007). Listado de imágenes de Angiospermas Monocotiledóneas amenazadas y naturalmente escasas de la $V$ región continental. Valparaíso: CONAF.

Correa, M. (1951). Notas sobre las orquídeas argentinas del género Habenaria. Notas Mus. La Plata, Bot., 15, 151-169.

Erdtman, G. (1960). The acetolysis method. A revised description. Sv. Bot. Tidskr., 54, 561-564.

Fitzgerald, M., Barnes, S., Blackmore, S., Calder, D. \& Knox, R. (1994). Pollen development and cohesion in a mealy and hard type of orchid pollinium. Int. F. Plant Sci., 155, 481-491.

García-Cruz, J., Jiménez Machorro, R., Sánchez Saldaña, L., Espejo Serna, A. \& López-Ferrari, A. R. (2000). Notas sobre el género Habenaria (Orchidaceae) en México. Acta Bot. Mex., 50, 27-38.

Hesse, M. (1981a). The fine structure of the exine in relation to the stickiness of angiosperm pollen. Rev. Paleobot. Palynol., 35, 81-92.

Hesse, M. (1981b). Pollenkitt and viscin threads: Their role in cementing pollen grains. Grana, 20, 145-152.

Hesse, M. (1986). Nature, form and function of pollen-connecting threads in angiosperms. In S. Blackmore \& I. K. Ferguson (Eds), Pollen and spores: Form and function (pp. 109-118). London: Acad. Press. Linn. Soc. Symp. Ser. 12.

Hesse, M. \& Burns-Balogh, P. (1984). Pollen and pollinarium morphology of Habenaria (Orchidaceae). Pollen et Spores, 26, 385-400.

Jackson, D. D. (1928). A glossary of botanic terms. London: Duckworth.

Kurzweil, H. \& Weber, A. (1992). Floral morphology of southern African Orchideae II. Habenariinae. Nord. f. Bot., 12, 39-61.

Pacini, E. \& Hesse, M. (2002).Types of pollen dispersal units in orchids, and their consequences for germination and fertilization. Ann. Bot., 89, 653-664.

Pridgeon, A. M., Cribb, P. J., Chase, M. W. \& Rasmussen, F. N. (2001). Genera Orchidacearum. Orchidoideae, 2. 1., New York: Oxford Univ. Press.

Punt, W., Hoen, P.P., Blackmore, S., Nilsson, S. \& Le Thomas, A. (2007). Glossary of pollen and spore terminology. Rev. Palaeobot. Palynol., 143, 1-81.

Schill, R. \& Pfeiffer, W. (1977). Untersuchungen an Orchideenpollinien unter besonderer Berücksichtigung ihrer Feinskulpturen. Pollen et Spores, 19, 5-118.

Schill, R. \& Wolter, M. (1986). On the presence of elastoviscin in all subfamilies of the Orchidaceae, and the homology to pollenkitt. Nord. F. Bot., 6, 321-324

Schlag, M. \& Hesse, M. (1993). Morphogenesis of the sporoderm in Polystachia pubescens (Orchidaceae). Grana, 32, 22-28.

Singer, R. B. (2001). The pollination biology of Habenaria parviflora (Orchidaceae-Habenariinae) in Southeastern Brazil. Darwiniana, 39, 201-207.

Takahashi, M. (1980). On the development of the reticulate structure of Hemerocallis pollen (Liliaceae). Grana, 19, 3-5.

Traub, H. P. \& Moldenke, H. N. (1949). Amaryllidaceae, Tribe Amarylleae. Stanford, CA: APLS.

Zavada, M. (1990). A contribution to the study of pollen wall ultrastucture of orchid pollinia. Ann. Mo. Bot. Gard., 77, 785-801. 